\title{
Flipped learning and formative evaluation in higher education
}

\author{
Fernando M. Otero-Saborido \\ Universidad Pablo de Olavide, Sevilla, Spain \\ Antonio J. Sánchez-Oliver and Moisés Grimaldi-Puyana \\ University of Sevilla, Sevilla, Spain, and \\ José Álvarez-García \\ Department of Financial Economics and Accounting, University of Extremadura, \\ Cáceres, Spain
}

\begin{abstract}
Purpose - The purpose of this paper is to design and validate a continuous self-assessment tool that involves university students in reflection processes on their Flipped Learning model learning.

Design/methodology/approach - For this, 66 students $(18.77 \pm 1.36)$ of the first year of the Degree in Physical Activity and Sports Sciences participated for nine weeks in the weekly completion of a self-assessment tool. The questionnaire followed a content validation by a group of experts and, subsequently, reliability was found from the internal consistency perspective through Cronbach's $\alpha$.

Findings - The results obtained show a reliable tool that facilitates the work by competencies in university education under the Flipped Learning model.

Originality/value - This work is the first step that responds to the almost non-existent practices of democratic evaluation in Higher Education. The design and validation of questionnaires that consider the measures adopted by the European Higher Education Area and that takes into account European Credit Transfer and Accumulation System is scarce.
\end{abstract}

Keywords Physical education, Questionnaire, Self-appraisal, Active methodologies

Paper type Research paper

\section{Introduction}

The predominance of traditional methodologies in higher education has been one of the predominant pedagogical features. This tendency has affected the evaluation as part of the entire teaching-learning process in the European Higher Education Area (EHEA). General evaluation approaches arise from the division of knowledge of Habermas (1992). That distinction can be summarized in technical rationalism and practical rationalism. Each model has specific characteristics that are transferred to their evaluative approaches (López Pastor, 2011). In the case of technical rationalism, the evaluative intention is the technical verification of the achievement of objectives and their efficiency through measurement. Teachers are passive executors of the measurement, which is designed by experts. At the other end, evaluation under practical rationalism does not aim to measure the results but to understand them. Effectiveness assessment disappears in favor of educational value. That is, the purpose of evaluation is to be of use for learning. Scriven in 1967 was responsible for coining this concept as "formative evaluation" (Jorba and Sanmartí, 2009). Although the first precedent related with formative evaluation is found in Dewey's pedagogy, which established learning focused on experience and its subsequent reflection (Dewey, 1916). In short, this is the procedure followed by formative evaluation: acting to then reflect on the action and generate learning in a new situation. This is the sequence that specific formative evaluation strategies develop, such as self-appraisal or co-assessment.

In the case of Physical Education (PE), evaluation has been rated as one of the most controversial aspects of the teaching-learning process in this area (James et al., 2005). Exporting the previous models to PE in Spain has a homogeneous description. The first
Flipped

learning and formative evaluation

Received 31 December 2017 Revised 12 January 2018 17 January 2018

Accepted 17 January 2018 
ET

60,5

model is focused on physical performance and aims to measure the effectiveness of the student's physical performance through tests and standardized test. This conception does not consider the educational value of the evaluation. Its aim is summarized by the question made by Lopez Pastor (2004) "Why do we say evaluation when we really mean mark?" In contrast, the model focused on student participation does have a high educational value. It does not only assess the motor function aspect, but also considers the affective, social and cognitive dimensions through students' involvement in the evaluation (López Pastor, 2011).

Following this same approach, different studies have shown the benefits of involving students by using self-appraisal and peer evaluation or co-assessment situations (Lamb et al., 2013; López Pastor, 2007; López Pastor, 2000; Moreno et al., 2005; Ní Chróinín and Cosgrave, 2013). The reviews of different studies on evaluation practices in different contexts and moments reveal that, although the theoretical paradigm indicates the prevalence of a formative evaluation, in the evaluative practices of PE teachers, appraisal models still predominate and with little participation by students (Lorente-Catalan and Kirk, 2013; Moreno-Murcia et al., 2013). Although there has been an increase in research on formative evaluation in $\mathrm{PE}$, there are still few studies that investigate tools such as peer evaluation and self-appraisal. In the same line, formative evaluation practices in PE classes are carried out despite contributions such as the Training and Shared Evaluation Network in Higher Education (López Pastor, 2007).

In any case, the predominance of traditional methodologies in higher education does not only affect evaluation, but also defines very static teacher and student roles. On the one hand, the teacher as a mere disseminator of knowledge and on the other hand, students receive this knowledge passively. The new paradigms aim to change the teacher's role, and make the teacher a figure who spends less time explaining and more time stimulating, guiding and supporting students (Flores et al., 2016). This is the case of the flipped classroom, which is implemented in this present study. The flipped classroom is a blended learning strategy, as it involves a combination of face-to-face and online components in the same course. The traditional or master class, often seen as ineffective for student engagement and learning, is replaced with online material, and the face-to-face physical class is used for active learning, such as problem-solving, group work, discussion and analysis (Wanner and Palmer, 2015).

The flipped classroom offers students opportunities to develop critical and independent thinking and improve their own learning processes by interacting collaboratively with their peers. In addition, teachers give their students more flexibility and freedom so they can learn from activities specially designed to improve their problem-solving skills (Thai et al., 2017).

Everything indicates that the model improves students' academic performance, as well as their commitment to the learning process. The student stops being a passive element and develops key skills such as: selecting information, teamwork, critical thinking and self-management and self-appraisal of the learning process (Hamdam et al., 2013).

There are several studies whose objective is to provide evidence on the effectiveness of the flipped classroom in the university context. In this way, Abeysekera and Dawson (2015) have recently studied what can be changed in traditional education to replace it with an education with more active methodologies, in which the flipped classroom is included; or Rivera (2015), who highlights the importance of efficient time management training, considering the flipped classroom model as a possible option.

Moraros et al. (2015) and Blair et al. (2016) have analyzed the flipped classroom and describe it as a methodology that helps students improve their academic level. Another criticism about the validity of the effectiveness of the current model is found in the Flipped Learning Network report (2012), which presents and analyzes some of the results of the application of the model. The report shows that of the 453 teachers who applied the flipped classroom model, 67 percent perceived an improvement in their students' results, 80 percent noticed an improvement in their 
students' attitude and 99 percent declared that they would flip their classrooms again (O'Flaherty and Phillips, 2015). Another interesting contribution to this list of evidence comes from Clintondale High School in Michigan, where the failure rate of its 9th grade students in the maths class dropped from 44 to 13 percent after applying the Flipped Classroom model (Finkel, 2012).

In the same line, the report by Yarbro et al. (2014) should also be highlighted, which collects data on a wide range of case studies in which the model was applied over different periods and levels of education. The results suggest that students' performance improved and both the teachers and students were more satisfied with the teaching process and results.

In addition, a critical school of thought is emerging that perceives some danger in the flipped methodology classroom. It believes in the possibility of the flipped classroom becoming a methodology of weak classes, where students and teachers can become increasingly disappointed and resistant to this delivery model (Wanner and Palmer, 2015). Despite its growing popularity as a teaching model, there is still limited evidence of its effectiveness in improving students' learning outcomes (Sharples et al., 2016; McNally et al., 2017). This is changing little by little with emerging studies on the benefits of the flipped classroom, in particular to increase student participation and interactive cooperative learning, but also to improve learning outcomes (Wanner and Palmer, 2015; Flores et al., 2016; Foldnes, 2016; Koo et al., 2016).

University-level teaching has been carried out in a relatively similar way for a very long period of time. University education and traditional master classes are being strongly criticized, since the student is treated as a passive entity. However, despite integral criticism, the traditional class continues to dominate as a predominant teaching strategy in higher education (Roehl et al., 2013).

With the implementation of the European Credit Transfer and Accumulation System (ECTS) in higher education, we begin to opt for a new methodology that places the student at the centre of the teaching-learning process (Grosges and Barchiesi, 2007). The aim is to evaluate both the teaching hours and the student's non-classroom work, including preparation time of evaluation tests, readings, seminars, etc.

In different educational forums, "the fiction of ECTS" is spoken of as a deficiency between the credits granted to a subject and the credit hours that the student develops outside the non-teaching hours (Gleeson, 2013). This deficit between ECTS and real hours is not only a quantitative issue, but is a problem of greater dimensions when questioning the pursued acquisition of skills and functional learning by students.

This fiction shows a deficiency between the credits granted to a subject (that integrate the classroom and non-classroom hours) and the credit hours that students actually develop during non-classroom hours. In this sense, the problem of the deficit between ECTS and real hours is not only quantitative, as was mentioned previously. We are facing a more important issue. The "fiction" of non-classroom work does not favor the contribution of the well-known learning skills of university students (Cano García, 2008). In response to this "fiction," active participation models such as Flipped Learning empower students' skills and favor the non-classroom activity approach posed by the ECTS system.

The initiatives must respond to "the fiction of ECTS." The strategies used should be understood as tools within the set of active methodologies that place students at the centre of learning. These approaches redefine the actors' roles in the process. Teachers stop being mere disseminators to acquire functions of mediators, facilitators and designers of learning environments. Students abandon the role of passive recipients and become empowered as a constructor of their learning (Herreid and Schiller, 2013).

Thus, we can say that, in the first place, evaluation practices are focused on performance measurement; second, the power of traditional methodologies in higher education is a reality and, third, that non-classroom work and, therefore, learning achievement through students' skills in the ECTS system, is not possible with the two previous circumstances.

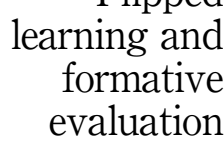

423 
ET

60,5

Therefore, the objective of this work was the design and validation of a continuous self-assessment tool that involves university students in reflection processes on their learning in the active model such as Flipped Learning. In addition, within the processes, the instrument was aimed at providing a qualitative and quantitative evaluation of the classroom and non-classroom work carried out on the subject.

\section{Methodology}

Participants

From an initial sample of 160 students, a total of $66(18.77 \pm 1.36)$ completed all the weekly self-appraisal questionnaires throughout the nine weeks. All the participants were first year students of the Degree in Physical Activity and Sports Science. Data collecting was carried out in the 2017-2018 academic year at the Pablo de Olavide University in Seville.

\section{Procedure}

For the purpose of this work, the instrument was validated completely following two phases: a validation of content and the reliability of the instrument. For the content validation, a group of experts determined the objectives of the tool: to collect the student's perception about work time dedicated to both classroom and non-classroom tasks; and to involve the students in the reflection of the elements of the teaching-learning process. Subsequently, a literature review was carried out related to two areas, on the one hand, formative evaluation through self-appraisal and, on the other hand, the Flipped Learning model. Given the objective and the context to implement the instrument, the group of experts determined that the final instrument should have two requirements. In the first place, the variables/categories should not be limited only to the students, but should include all the teaching-learning agents/elements: teacher, content and/or process. Second, it was agreed that the final instrument would have a small number of items since it would be completed by the students weekly over a semester. After a circulation process of the questionnaire, the initial instrument of 12 questions was reduced to 8 final questions.

\section{Instrument}

The eight questions of the questionnaire were as follows. The objective of the first two questions/categories was for students' self-appraisal and to evaluate both their classroom and non-classroom work time. These questions had an open response format. The aim of questions 3, 4 and 5 was for the students to reflect on the entire teaching-learning process including their involvement (question 3), the evaluation of the whole process (question 4) and satisfaction with teaching. These questions contained a Likert-type scale with four response options and each one is a qualitative question to justify the answer. Subsequently, the participating students completed the evaluation instrument designed by the experts weekly, adding a total of nine questionnaires for each student. Its variables and categories are shown in Table I.

\section{Analysis}

Once the data were collected, it was analyzed through the statistical package SPSS v.15. In addition, reliability levels were obtained through Cronbach's $\alpha$ in the different categories of each question, finding their levels of significance.

\section{Results and discussion}

The results obtained show good and excellent Cronbach's $\alpha$ coefficients in 12 of the 14 categories of the self-appraisal instrument (Table II). The coefficient obtained in the "BE" category $(0.375)$ is questionable and of the "PT" category unacceptable $(0.107)$, both in 


\begin{tabular}{|c|c|c|c|c|}
\hline Variables & Categories & Response options & Qualitative questions & $\begin{array}{l}\text { Flipped } \\
\text { learning and }\end{array}$ \\
\hline 1.Amount of students' classroom activity & $\begin{array}{l}\text { Basic education } \\
\text { Practical teaching } \\
\text { Face-to-face tutoring }\end{array}$ & Open question & No & $\begin{array}{l}\text { formative } \\
\text { evaluation }\end{array}$ \\
\hline \multirow[t]{2}{*}{ 2.Amount of non-classroom activity } & $\begin{array}{l}\text { Reading texts } \\
\text { Watching videos } \\
\text { Virtual tutoring }\end{array}$ & Open question & No & 425 \\
\hline & $\begin{array}{l}\text { Preparation of } \\
\text { practical work } \\
\text { Studying for exams } \\
\text { Self-appraisal } \\
\text { Others } \\
\text { Total non-classroom }\end{array}$ & & & \\
\hline 3. Involvement of students & & $\begin{array}{l}\text { 1. Not at all involved } \\
\text { 2. Hardly involved } \\
\text { 3. Involved } \\
\text { 4. Very Involved }\end{array}$ & Yes & \\
\hline 4. Usefulness of student learning & & $\begin{array}{l}\text { 1. Useless } \\
\text { 2. Hardly useful } \\
\text { 3. Useful } \\
\text { 4. Very useful }\end{array}$ & Yes & \\
\hline 5. Satisfaction with teaching & & $\begin{array}{l}\text { 1. Dissatisfied } \\
\text { 2. Hardly satisfied } \\
\text { 3. Satisfied } \\
\text { 4. Very satisfied }\end{array}$ & Yes & $\begin{array}{l}\text { Table I. } \\
\text { Variables and } \\
\text { categories of the } \\
\text { evaluation instrument } \\
\text { resulting after }\end{array}$ \\
\hline Source: Own elaboration & & & & content validation \\
\hline
\end{tabular}

\begin{tabular}{llcccl}
\hline Variable & Categories & Number of items & Cronbach's $\alpha$ & $F$ & Sig. \\
\hline Amount of students' classroom activity & BE & 9 & 0.375 & 3.134 & $0.002^{* * *}$ \\
& PT & 9 & 0.107 & 1.539 & 0.141 \\
& FTFT & 9 & 0.931 & 2.205 & $0.026^{*}$ \\
Amount of non-classroom activity & RT & 9 & 0.870 & 23.584 & $0.000^{* *}$ \\
& WV & 9 & 0.827 & 30.346 & $0.000^{* *}$ \\
& VT & 9 & 0.895 & 0.6050 & 0.774 \\
& PPW & 9 & 0.671 & 126.326 & $0.000^{* *}$ \\
& SA & 9 & 0.9193 & 3.710 & $0.000^{* *}$ \\
& SA & 9 & 0.814 & 1.111 & 0.426 \\
& O & 9 & 0.846 & 9.70 & $0.000^{* *}$ \\
Involvement of students & TNP & 9 & 0.925 & 79.5618 & $0.000^{* *}$ \\
Usefulness of student learning & & 9 & 0.751 & 10.516 & $0.000^{* *}$ \\
Satisfaction with teaching & & 9 & 0.607 & 6.840 & $0.000^{* *}$ \\
N & & 9 & 0.6885 & 3.24 & $0.000^{* *}$
\end{tabular}

Notes: BE, basic education; PT, practical teaching; FTFT, face-to-face tutoring; RT, reading texts; WV, watching videos; VT, virtual tutoring; PPW, preparation of practical work; SE, studying for exams; SA, self-appraisal; O, others; TNC, total non-classroom. $* * p<0.05 ; * * p<0.001$

Source: Own elaboration

Table II. Internal consistency of the variables and categories of the self-assessment instrument

Amount of Students' Classroom Activity. Note that in 11 of the 14 categories, the internal consistency is very significant $(p<0.001)$. Although all the coefficients are not quantitatively good, the instrument can be considered globally relevant if the sample size is taken into account $(n=66)$ and the data obtained are not obtained to make subsequent experimental decisions. 
ET

60,5

Most of the papers reviewed on Flipped Learning do not use evaluation instruments or those used have not been validated (Touron and Santiago, 2015; DeLozier and Rhodes, 2017; O'Flaherty and Phillips, 2015; Lo and Hew, 2017). Although there are several studies that design and validate questionnaires on academic satisfaction, aspects involved in the teaching-learning process or in the academic context of higher education (Gento Palacios and Vivas García, 2003, Cabrera and Galán, 2002, Cusó et al., 2015), the bibliography on design and validation of questionnaires to evaluate the flipped model in the university context is non-existent. The same occurs with validated self-appraisal questionnaires in the university context, where we find questionnaires of self-appraisal by the student on issues related to higher education (Joo and Dennen, 2017; Rodríguez Gómez et al., 2013), but not self-appraisal in active methodologies such as the Flipped methodology.

The design and validation of questionnaires that consider the measures adopted by the EHEA and that takes into account ECTS is scarce. The reviewed bibliography shows that the validated instruments within the Flipped model are not aimed at assessing students' non-classroom work or their involvement continuously, but rather that students specifically assess the Flipped Learning model (Flores et al., 2016), except for the recent study by Otero-Saborido et al. (2017) that considers it and shows some very similar results, thus reinforcing the properties and usefulness of the questionnaire. This issue has not been overlooked, and the present study has quantified both the teaching hours and the student's non-classroom work, including the preparation time of evaluation tests, readings, seminars, etc., and thus giving an answer to "the fiction of ECTS" (Gleeson, 2013), previously mentioned.

Taking into account students' perceptions about the teaching-learning process in order to be more effective in university evaluation processes is of vital importance, and this has not been sufficiently taken into account in the experimentation with the existing ECTS. In the long run, they can affect processes that evaluate the quality of education and the quality of the university itself (De la Fuente et al., 2011).

Many universities are increasingly opting for learning-oriented evaluation approaches and for learning evaluations by the students for their academic regulations (Black et al., 2004; Fisher et al., 2011). However, in higher education there is still a challenging need to complement summative evaluation systems (focusing on the final test and marks) with more learning-oriented systems. The relevant literature points to a crisis in the implementation of formative evaluation due to the particular pressures on learning and teaching that are experienced in education today (Gikandi et al., 2011). Precisely here lies the difference of this work with similar studies (Otero-Saborido et al., 2017), since the application of this work was done in a context with greater and more profound formative evaluation practices (Reimann and Sadler, 2017), such as the dialogic mark and co-assessment. As stated in the existing literature, formative evaluation can improve learning and, therefore, contribute to the development of future professionals (López-Pastor and Sicilia-Camacho, 2015). In this way, the designed and validated questionnaire can be a tool that enables to analyze formative evaluation practices within the contexts in which they are developed and from the point of view of the student, who is the main actor in active methodologies such as the Flipped one.

Therefore, this work is the first step that responds to the almost non-existent practices of democratic evaluation in Higher Education, as reflected in some recent reviews about it (Lau, 2016; Baleni, 2015; Reimann and Sadler, 2017). As an extension of the design and validation of a self-appraisal questionnaire prepared by Otero-Saborido et al. (2017), this proposal includes more democratic evaluation practices such as the dialogic mark and co-assessment case. Likewise, innovation is also inserted within an innovative model such as flipped learning, which was applied throughout the semester.

Empirical research on the flipped classroom model in higher education, and more detailed investigations of the perceptions of its use in students, is only just beginning. 
The need for further research is highlighted by experts (Uzunboylu and Karagozlu, 2015; Betihavas et al., 2016; Gilboy et al., 2015). Therefore, even though evidence of the effectiveness of the model and its advantages is appearing gradually (Touron and Santiago, 2015), the results of these publications are still in the embryonic phase, requiring more studies to assess the effectiveness of the Flipped model (Goodwin and Miller, 2013).

The inclusion of new innovative educational perspectives allows students and university professors to remain competitive, going beyond the current status quo (Ratten, 2017). In addition, it is important to investigate these new lines of work to know them better and to know if their use is being adequate, since it has been seen that there are innovative educational proposals that are not giving the expected result (Packham et al., 2004). The use of innovative educational tools must pay attention to the improvement of quality and the enrichment of learning by designing curricula that integrate them (Onstenk and Blokhuis, 2007).

\section{Conclusions}

Given the need to introduce and generalize competency approaches in university education, this work fulfills the objective of designing and validating a questionnaire that involves students in mechanisms of reflection on their teaching-learning process. As an added value of the validated tool, it should be noted that it is applied in a Flipped Learning model and that, above all, students are involved in the assessment of their non-classroom work, which is so important in the ECTS system and for the acquisition of generic and specific skills of university students.

\section{Implications, limitations and future lines of research}

The findings suggest that the strategies used (Flipped Learning and Formative Assessment) should be understood as tools within the set of active methodologies that place students at the center of learning. These approaches redefine the roles of the protagonists of the teaching-learning process. Teachers must stop being mere transmitters to acquire the functions of mediators, facilitators and designers of learning environments, in turn, responding to "the fiction of ECTS." On the other hand, students must abandon the role of passive receiver and empower themselves as constructors of their learning.

The size of the sample and the use of the self-reported questionnaire are shown as the main limiting factors of the article. Other limitation of this report is that the results focus only on students' auto assessment regarding their experience. However, it is valuable to understand students' perceptions and these findings are promising for future studies within the discipline. Specifically, future research can examine grades from different assessments (e.g. exams, papers, and projects) and not only self-assessment. In addition, as previously noted, because of the novelty of this teaching and assessment approach, there is limited educational out-come research on the effectiveness of the both in high education.

Future research should consider the relationship of other indicators of student engagement in the Flipped Class (not just examination scores). Constructs such as engagement are not always easily reduced o measurable items on survey instruments or a reflection of examination performance and so warrant further investigation. For example, utilizing online activity as a measure to quantitate student engagement, though important, is only one variable known to impact on student development. Determine the relationship between academic performance and the use of formative assessment tools such as the validated questionnaire could be other possible lines of future research.

\section{learning and formative evaluation}


ET

60,5

\section{References}

Abeysekera, L. and Dawson, P. (2015), "Motivation and cognitive load in the flipped classroom: definition, rationale and a call for research", Higher Education Research and Development, Vol. 34 No. 1, pp. 1-14.

Baleni, Z.G. (2015), “Online formative assessment in higher education”, Electronic Journal of e-Learning, Vol. 13 No. 4, pp. 228-236.

Betihavas, V., Bridgman, H., Kornhaber, R. and Cross, M. (2016), “The evidence for 'flipping out': a systematic review of the flipped classroom in nursing education", Nurse Education Today, Vol. 38, pp. 15-21.

Black, P., Harrison, C. and Lee, C. (2004), Assessment for Learning: Putting it into Practice, McGraw-Hill Education.

Blair, E., Maharaj, C. and Primus, S. (2016), "Performance and perception in the flipped classroom", Education and Information Technologies, Vol. 21 No. 6, pp. 1465-1482.

Cabrera, P. and Galán, E. (2002), "Satisfacción escolar y rendimiento académico", Revista De Psicodidactica No. 14, pp. 87-98.

Cano García, E. (2008), "La evaluación por competencias en la educación superior", Profesorado: Revista De Currículum y Formación Del Profesorado, Vol. 12 No. 3, pp. 1-16.

Cusó, F.J.P., Clares, P.M. and Juárez, M.M. (2015), "Satisfacción del estudiante universitario con la tutoría. diseño y validación de un instrumento de medida", Estudios Sobre Educacion, Vol. 29, pp. 81-101.

De la Fuente, J., Cardelle-Elawar, M., Peralta, F.J., Sánchez, M.D., Martínez-Vicente, J.M. and Zapata, L. (2011), 'Students' factors affecting undergraduates' perceptions of their teaching and learning process within ECTS experience", Frontiers in Psychology, Vol. 2 No. 28, pp. 1-10.

DeLozier, S.J. and Rhodes, M.G. (2017), "Flipped classrooms: a review of key ideas and recommendations for practice", Educational Psychology Review, Vol. 29 No. 1, pp. 141-151.

Dewey, J. (1916), Democracy and Education: An Introduction to the Philosophy of Education, Free Press, New York, NY.

Finkel, E.D. (2012), "Flipping the script in K12”, District Administration, Vol. 48 No. 10, pp. 28-34.

Fisher, R., Cavanagh, J. and Bowles, A. (2011), "Assisting transition to university: using assessment as a formative learning tool", Assessment and Evaluation in Higher Education, Vol. 36 No. 2, pp. 225-237.

Flores, Ò., del-Arco, I. and Silva, P. (2016), "The flipped classroom model at the university: analysis based on professors' and students' assessment in the educational field", International Journal of Educational Technology in Higher Education, Vol. 13 No. 1, pp. 1-12.

Foldnes, N. (2016), "The flipped classroom and cooperative learning: evidence from a randomised experiment", Active Learning in Higher Education, Vol. 17 No. 1, pp. 39-49.

Gento Palacios, S. and Vivas García, M. (2003), "El SEUE: un instrumento para conocer la satisfacción de los estudiantes universitarios con su educación”, Acción Pedagógica, Vol. 12 No. 2, pp. 16-27.

Gikandi, J.W., Morrow, D. and Davis, N.E. (2011), "Online formative assessment in higher education: a review of the literature", Computers and Education, Vol. 57 No. 4, pp. 2333-2351.

Gilboy, M.B., Heinerichs, S. and Pazzaglia, G. (2015), "Enhancing student engagement using the flipped classroom", Journal of Nutrition Education and Behavior, Vol. 47 No. 1, pp. 109-114.

Gleeson, J. (2013), "The European credit transfer system and curriculum design: product before process?”, Studies in Higher Education, Vol. 38 No. 6, pp. 921-938.

Goodwin, B. and Miller, K. (2013), "Evidence on flipped classrooms is still coming in", Educational Leadership, Vol. 70 No. 6, pp. 79-80.

Grosges, T. and Barchiesi, D. (2007), "European credit transfer and accumulation system: an alternative way to calculate the ECTS grades", Higher Education in Europe, Vol. 32 No. 2-3, pp. 213-227.

Habermas, J. (1992), Teoría De La Acción Comunicativa, I. Racionalidad De La Acción Y Racionalización Social, Volumen 1, Taurus Humanidades, Madrid. 
Hamdam, N., McKnight, P., McKnight, K. and Arfstrom, K.M. (2013), "The flipped learning model: a white paper based on the literature review titled a review of flipped learning", Flipped Learning Network, pp. 1-15, available at: http://researchnetwork.pearson.com/wpcontent/ uploads/WhitePaper_FlippedLearning.pdf (accessed December 15, 2017).

Herreid, C.F. and Schiller, N.A. (2013), "Case studies and the flipped classroom", Journal of College Science Teaching, Vol. 42 No. 5, pp. 62-66.

James, A.R., Griffin, L.L. and France, T. (2005), "Perceptions of assessment in elementary physical education : a case study", Physical Educator, Vol. 62 No. 2, pp. 85-95.

Joo, M.H. and Dennen, V.P. (2017), "Measuring university students' group work contribution: scale development and validation", Small Group Research, Vol. 48 No. 3, pp. 288-310.

Jorba, J. and Sanmartí, N. (2009), "La función pedagógica de la evaluación”, Aula De Innovación Educativa, No. 20, pp. 20-30.

Koo, C.L., Demps, E.L., Farris, C., Bowman, J.D., Panahi, L. and Boyle, P. (2016), "Impact of flipped classroom design on student performance and perceptions in a pharmacotherapy course", American Journal of Pharmaceutical Education, Vol. 80 No. 2, pp. 1-9.

Lamb, P., Lane, K. and Aldous, D. (2013), "Enhancing the spaces of reflection: a buddy peer-review process within physical education initial teacher education", European Physical Education Review, Vol. 19 No. 1, pp. 21-38.

Lau, A.M.S. (2016), "Formative good, summative bad?-A review of the dichotomy in assessment literature", Journal of Further and Higher Education, Vol. 40 No. 4, pp. 509-525.

Lo, C.K. and Hew, K.F. (2017), "A critical review of flipped classroom challenges in $K$-12 education: possible solutions and recommendations for future research", Research and Practice in Technology Enhanced Learning, Vol. 12 No. 1, pp. 1-22.

López-Pastor, V. and Sicilia-Camacho, A. (2015), "Formative and shared assessment in higher education: lessons learned and challenges for the future", Assessment \& Evaluation in Higher Education, Vol. 42 No. 1, pp. 77-97.

López Pastor, V.M. (2000), "Buscando una evaluación formativa en educación física: análisis crítico de la realidad existente, presentación de una propuesta y análisis general de su puesta en práctica", Apunts: Educación Física Y Deportes, Vol. 4 No. 62, pp. 16-26.

Lopez Pastor, V.M. (2004), "Evaluación, calificación, credencialismo y formación inicial del profesorado: efectos y patologías generadas en la enseñanza universitaria”, Revista Interuniversitaria De Formación Del Profesorado, Vol. 18 No. 3, pp. 221-232.

López Pastor, V.M. (2007), "La evaluación en educación física y su relación con la atención a la diversidad del alumnado. Aportaciones, ventajas y posibilidades desde la evaluación formativa y compartida”, Kronos. Enseñanza De La Actividad Física Y el Deporte, Vol. V No. 11, pp. 10-15.

López Pastor, V.M. (2011), "Best practices in academic assessment in higher education: a case in formative and shared assessment", JOTSE, Vol. 1 No. 2, pp. 25-39.

Lorente-Catalan, E. and Kirk, D. (2013), "Making the case for democratic assessment practices within a critical pedagogy of physical education teacher education”, European Physical Education Review, Vol. 20 No. 1, pp. 104-119.

McNally, B., Chipperfield, J., Dorsett, P., Del Fabbro, L., Frommolt, V., Goetz, S., Lewohl, J., Molineuxe, M., Pearson, A., Roiko, A. and Rung, A. (2017), "Flipped classroom experiences: student preferences and flip strategy in a higher education context", Higher Education, Vol. 73 No. 2, pp. 281-298.

Moraros, J., Islam, A., Yu, S., Banow, R. and Schindelka, B. (2015), "Flipping for success: evaluating the effectiveness of a novel teaching approach in a graduate level setting", BMC Medical Education, Vol. 15, pp. 1-10.

Moreno-Murcia, J.A., Aracil, A. and Reina, R. (2013), "La cesión de responsabilidad en la evaluación: una estrategia adaptada al espacio Europeo de educación superior", Educacion XX1, Vol. 17 No. 1, pp. 183-199.

Moreno, J., Vera, J. and Cervelló, E. (2005), "Evaluación participativa y responsabilidad en Educación Física”, Revista de Educación, Vol. 340, pp. 731-754.

\section{learning and formative evaluation}

Flipped 
ET

60,5

Ní Chróinín, D. and Cosgrave, C. (2013), "Implementing formative assessment in primary physical education: teacher perspectives and experiences”, Physical Education \& Sport Pedagogy, Vol. 18 No. 2, pp. 219-233.

O'Flaherty, J. and Phillips, C. (2015), "The use of flipped classrooms in higher education: a scoping review", Internet and Higher Education, Vol. 25, pp. 85-95.

Onstenk, J. and Blokhuis, F. (2007), "Apprenticeship in the Netherlands: connecting school- and workbased learning", Education+Training, Vol. 49 No. 6, pp. 489-499.

Otero-Saborido, F.M., Sánchez-Oliver, A. and Fuentes-García, I. (2017), "Diseño y validación de un instrumento de autoevaluación del alumnado universitario dentro del Modelo Flipped Learning”, Revista Infancia, Educación y Aprendizaje, Vol. 3 No. 2, pp. 735-740.

Packham, G., Jones, P., Miller, C. and Thomas, B. (2004), "E-learning and retention: key factors influencing student withdrawal", Education+Training, Vol. 46 Nos 6/7, pp. 335-342, available at: www.emeraldinsight.com/ doi/10.1108/00400910410555240

Ratten, V. (2017), "Entrepreneurial sport policy", International Journal of Sport Policy, Vol. 9 No. 4, pp. 641-648.

Reimann, N. and Sadler, I. (2017), "Personal understanding of assessment and the link to assessment practice: the perspectives of higher education staff", Assessment and Evaluation in Higher Education, Vol. 42 No. 5, pp. 724-736.

Rivera, E. (2015), "Using the flipped classroom model in your library instruction course", The Reference Librarian, Vol. 56 No. 1, pp. 34-41.

Rodríguez Gómez, G., Ibarra Sáiz, M.S. and García Jimenez, E. (2013), "Autoevaluación, evaluación entre iguales y coevaluación: conceptualización y práctica en las universidades españolas", Revista de Investigacion en Educación, Vol. 11 No. 2, pp. 198-210.

Roehl, A., Reddy, S.L. and Shannon, G.J. (2013), "The flipped classroom: an opportunity to engage millennial students through active learning strategies", Journal of Family \& Consumer Sciences, Vol. 105 No. 2, pp. 44-49.

Sharples, M., de Roock, R., Ferguson, R., Gaved, M., Herodotou, C., Koh, E., Kukulska-Hulme, A., Looi, C.-K., McAndrew, P., Rienties, B., Weller, M. and Wong, L.H. (2016), "Innovating pedagogy 2016: open university innovation report 5”, The Open University, Milton Keynes, available at: https://ec.europa.eu/jrc/sites/default/files/2014-nmc-horizon-report-eu-en_online.pdf (accessed December 15, 2017).

Thai, N.T.T., De Wever, B. and Valcke, M. (2017), "The impact of a flipped classroom design on learning performance in higher education: looking for the best 'blend' of lectures and guiding questions with feedback", Computers and Education, Vol. 107, pp. 113-126.

Touron, J. and Santiago, R. (2015), "Flipped learning model and the development of talent at school", Revista De Educacion, No. 368, pp. 33-65, available at: www.mecd.gob.es/revista-de-educacion/numerosrevista-educacion/ numeros-anteriores/2015/368/368_8.html (accessed December 15, 2017).

Uzunboylu, H. and Karagozlu, D. (2015), "Flipped classroom: a review of recent literature", World Journal on Educational Technology, Vol. 7 No. 2, pp. 142-147.

Wanner, T. and Palmer, E. (2015), "Personalising learning: exploring student and teacher perceptions about flexible learning and assessment in a flipped university course", Computers \& Education, Vol. 88, pp. 354-369.

Yarbro, J., Arfstrom, K.M., McKnight, K. and McKnight, P. (2014), "Extension of a Review of Flipped Learning", Flipped Learning Network, available at: https://flippedlearning.org/wp-content/uploads/20 16/07/Extension-of-FLipped-Learning-LIt-Review-June-2014.pdf (accessed December 15, 2017).

\section{Corresponding author}

José Álvarez-García can be contacted at: pepealvarez@unex.es

For instructions on how to order reprints of this article, please visit our website:

www.emeraldgrouppublishing.com/licensing/reprints.htm

Or contact us for further details: permissions@emeraldinsight.com 